The $5^{\text {th }}$ International Conference on Family Business and Entrepreneurship

\title{
THE EFFECT OF SOCIAL CAPITAL ON INNOVATION THROUGH THE MEDIATION OF AMBIDEXTERITY AND KNOWLEDGE SHARING IN CEMENT INDUSTRY
}

\author{
Safira Andriani ${ }^{*}$, Yasmine Nasution ${ }^{2}$ \\ ${ }^{1,2}$ Faculty of Economics and Business, Universitas Indonesia \\ Corresponding author: safira.andriani@ui.ac.id
}

\begin{abstract}
:
Indonesia's economy is in a precarious state, made worse by the presence of the corona virus disease 2019 (Covid-19) pandemic. As a result, it is critical for businesses to be able to adapt to changes in an uncertain business environment. One option for the business to endure is through innovation. Previous study has established that social capital, the ability of the work team to be ambidextrous and knowledge sharing play a critical role in the creation of innovation inside the organization. The purpose of this study is to examine the effect of social capital on innovation through the mediation of ambidexterity and knowledge sharing in work teams at PT Indocement Tunggal Prakarsa Tbk, one of the largest private cement companies in Indonesia. The company operates in an unstable environment due to the global crisis, politics, price competition, and excess cement production capacity in Indonesia since 2016. This research is quantitative research with purposive sampling method using Structural Equation Modeling (SEM) analysis with Partial Least Square (PLS) method to test the hypothesis. The study's findings demonstrate that social capital can influence the generation of innovation when it is mediated through ambidexterity and knowledge sharing. This research is expected to assist enterprises in the Indonesian cement sector in surviving by fostering innovation within each work team.
\end{abstract}

Keywords: social capital, ambidexterity, knowledge sharing, innovation, cement industry

\section{Introduction}

The world economy is in a fragile state, exacerbated by the presence of Covid-19 pandemic and the lingering effects of trade conflicts between the United States and China that began in 2018. In general, the business environment's state will always fluctuate. This might create an unstable climate for businesses and enhance fierce competitiveness. As a result, it is critical for businesses to be able to adapt to a sustainable environment while also maintaining the capacity to compete in a competitive economy. One strategy for sustaining the company's growth and competitiveness is to become more innovative (Amarakoon et al., 2018). Innovation is created not only for strategic advantage but also needed so that companies can thrive in a dynamic market.

At the moment, the local cement market is highly unpredictable due to the global crisis, politics, price rivalry, and Indonesia's surplus cement production capacity since 2016 (PT Indocement Tunggal Prakarsa Tbk Annual Report, 2018). Domestic cement sales also fell to 62.51 million tons in 2020, down 10.8 percent from the previous year, based on data from the Ministry of Industry. Despite the decline in demand for cement products, national cement production capacity grew. In 2020, the excess supply of national cement market reached 53 million tons (PT Indocement Tunggal Prakarsa Tbk Annual Report, 2020).

The excess supply of national cement will eventually affect the competitive competition in the national cement market. Although the government has initiated infrastructural development, this impact only affects Semen Indonesia, a state-owned enterprise (BUMN). While other private cement producers continued to 
face barriers to their cement sales. In the end, PT Holcim, which is a private cement company, was acquired by Semen Indonesia in 2018. PT Indocement, one of the major private cement firms in Indonesia, has managed to remain independent until today. With competitive pressures increasing, the company's strategy must be continually renewed. Businesses must be more inventive and capable of developing more effective work units in order to survive and adapt to fast market changes.

Previous research has established that social capital, ambidexterity, and knowledge sharing all have the ability to foster innovation (Andriopoulos \& Lewis, 2009; Wang \& Noe, 2010; Lin et al., 2013; Allameh, 2018). By developing social capital, it is possible to establish a strong bond and trust between members of a business, which facilitates decision-making and the exchange of information and knowledge (Chow \& Chan, 2008; Kostopoulos \& Bozionelos, 2011), allowing for the creation of innovation from the idea that emerges during the process. The literature also states that innovation can be created if the company's exploitative and exploratory activities can be balanced (Andriopoulos \& Lewis, 2009; Lin et al, 2013). These exploration and exploitation activities are referred as ambidexterity, which occurs when an organization engages in two distinct activities concurrently (Carlsson, 1989; Adler et al., 1999). While knowledge sharing is a way through which employees may exchange information and contribute to its application, the activity has the ability to contribute to the company's innovation and competitive advantage (Wang \& Noe, 2010). As a result of the critical role of innovation, this study seeks to determine whether the social capital owned by each work team in the company, as mediated by ambidexterity and knowledge sharing, has an effect on the creation of innovation required by companies in the Indonesian cement industry to survive in the country's unstable economic conditions.

\section{Literature Review and Hypotheses}

Social Capital and Ambidexterity

Social capital is a means of transferring and integrating information and ideas (Kang \& Snell, 2009), both institutional and non-institutional, which is critical for the firm to have. Social capital is critical for addressing organizational needs and can help businesses survive in today's competitive climate. Individuals, groups, and businesses with social capital can collaborate successfully to fulfill their responsibilities and may also foster a feeling of community via collaboration or cooperation. By establishing trust, efficient communication can be established, allowing the business to survive in a dynamic market (Cohen \& Prusak, 2001). Numerous research have been conducted on the notion of social capital organizations and their multifaceted character (Leana \& Van Buren, 1999; Bolino et al., 2002). Social capital has three aspects, according to Nahapiet and Ghoshal (1998). They include structural capital, relational capital, and cognitive capital. The frequency of contacts between team members and the intensity of the relationship between team members serve as a general indication of the structural aspects of capital. The relational aspects refer to the ties that exist between or among persons, such as trust, standards, and duties. Meanwhile, Cognitive Capital is comprised of an organization's members sharing a common purpose, vision, and value (Wasko \& Faraj, 2005).

Ambidexterity, according to organizational literature, refers to an organization's capacity to pursue two distinct objectives concurrently (Carlsson, 1989; Adler et al., 1999). March (1991) argues that exploitation and exploration are essentially distinct learning processes that the firm need to allocate its attention and resources differently. Exploitation includes actions such as the enhancement, efficiency, and use of the company's capabilities, whereas exploration includes experimenting, discovering and developing new capabilities (Danneels, 2002; Katila \& Ahuja, 2002). This method, conceptually, enables synergies between exploration and exploitation (Cao, Gedajlovic, \& Zhang, 2009). Organizations with ambidexterity may accomplish their members' objectives effectively while being adaptable to changes in their environment (Gibson \& Birkinshaw, 2004). As a result, this capability can eventually motivate higher performance within the organization and build a sustainable competitive advantage over time.

A work team that has strong internal ties can have good communication, a strong sense of community, and can reach consensus (Reagans \& McEvily, 2003). Even if members of a work team have confidence in one another, when they have opposing ideas or points of view, they may work together to address the issue (Kostopoulos \& Bozionelos, 2011). Equalizing and harmonizing members of an organization in exploration and exploitation activities is not simple, as conflict frequently arises when members hold divergent views. Thus, social capital is required to ensure that a work team's members have strong relationships and trust, enabling them to create synergies in their exploration and exploitation activities (Mom et al., 2009). Social capital can also serve as a bridge between a work team and external parties (for example, company employees outside the work team, customers, suppliers, and alliance partners), allowing them to gain access to a broader and more diverse pool of knowledge in order to update and improve their knowledge (Tiwana, 
2008). Additionally, prior study has established that social capital has a direct effect on the ambidexterity possessed by a work team (Kostopoulos, Bozionelos, \& Syrigos, 2015). Therefore, this study was conducted to find out whether social capital have a beneficial effect on ambidexterity in the context of the national cement industry, enabling businesses in the cement sector to survive and adapt to changes in their environment.

H1. Social Capital has a positive effect on ambidexterity

\section{Social Capital and Knowledge Sharing}

Knowledge sharing is a method through which employees may exchange information and contribute to the application of that information (Wang \& Noe, 2010). Knowledge sharing refers to the interchange of information on work routines, personal capabilities, and experiences inside an organization ( $\mathrm{Lu}$ et al., 2006). Nonaka and Takeuchi (1995) presented a model of Socialization, Externalization, Combination, and Internalization (SECI) based on Polanyi's (1966) conceptualization, which described tacit and explicit knowledge sharing in the knowledge sharing process. On the one hand, knowledge sharing has the potential to transform organizational information into individual or group knowledge via the internalization and socialization processes that underpin tacit knowledge sharing. On the other hand, knowledge sharing has the potential to transform individual and group information into organizational knowledge via the externalization process and a fusion of knowledge inside the organization, which is the foundation for explicit knowledge sharing (Wang \& Wang, 2012). Explicit knowledge is readily comprehended, documented, and communicated through management mechanisms such as processes, formal languages, manuals, and information technology systems, making explicit knowledge sharing more prevalent in the workplace (Coakes, 2006; Huang, Davison, \& Gu, 2010). Face-to-face interaction, on the other hand, is the primary mode of Tacit Knowledge Sharing. Individuals' desire and capacity to communicate what they know and learn is critical for Tacit Knowledge Sharing (CP Lin, 2007; HF Lin, 2007; Lee Endres et al., 2007; Holste \& Fields, 2010).

Chow and Chan (2008) emphasize the importance of social networks (structural capital), social trust (relational capital) and shared goals (cognitive capital) to encourage knowledge sharing. Organizations having strong network ties amongst their members can more easily carry out collective actions (Akhavan \& Hosseini, 2015). Networks help facilitate the exchange and gathering of information and pave the way for collaboration and interaction. Through access to a large number of individuals with relevant expertise, social network capital (structural capital) influences knowledge sharing (Van den Hooff \& Huysman, 2009). Social trust (relational capital) is a component that influences knowledge sharing and is frequently cited as a primary motivator of knowledge sharing (Kim \& Lee, 2010). Individuals are frequently hesitant to share their information with others, he believes that the knowledge he possesses may provide him with an advantage over other persons (Lin, 2007). Whereas cognitive capital relates to how well workers grasp the organization's aims and value, as well as their level of devotion to the organization's circumstances (abili, 2011). Additionally, prior study indicates that social capital has an effect on knowledge sharing (Chow and Chan, 2008; Van den Hoof and Huysman, 2009; Kim et al., 2012; Hu and Randel, 2014; Allameh, 2018). Therefore, based on the explanation above, this study was conducted to find out whether social capital can also encourage knowledge sharing in the context of the national cement industry.

H2. Social Capital has a positive effect on knowledge sharing

\section{Ambidexterity and Knowledge Sharing}

Ambidexterity is the capacity to achieve group goals while being efficient and adaptive to changes in the corporate environment (Buyl et al, 2012). One way for work teams to encourage knowledge sharing and achieve great performance is to increase their ambidexterity (Raisch \& Birkinshaw, 2008; Wang et al, 2017). Ambidextrous work teams are good at synchronizing their resources to pursue a high level of exploration and exploitation in a balanced way (Raisch \& Birkinshaw, 2008; Kauppila, 2010), their team members are more likely to maintain an attitude in which their primary focus is not on overall victory, but on growth and mastery of team tasks (He et al., 2014). These qualities are unquestionably advantageous in teamwork (Suarez, 2001). The work team can successfully engage in collective behavior and accomplish a variety of objectives (Simsek et al., 2005). Ambidexterity enables a work team to leverage current capabilities while also exploring new prospects without being distracted by competing aims, therefore these abilities can facilitate the performance and knowledge management on the work team (Raisch \& Birkinshaw, 2008). Additionally, prior study indicates that ambidexterity has a favorable correlation with knowledge sharing (Liu \& Lin et al., 2019). Therefore, this study supports that ambidexterity can also have a positive effect on knowledge sharing in the context of the national cement industry. 


\section{H3. Ambidexterity has a positive effect on knowledge sharing}

\section{Ambidexterity and Innovation}

According to West \& Farr (1989) innovation is defined as intentional generation, promotion, realization of new ideas in a work role, group or organization. Innovation can be in the form of new products, services, technology, structures or programs related to the organization (Damanpour, 1991). Innovation is a means of responding to internal or external changes in a business, as well as a means of influencing its information (Damanpour, 1991). Thus, innovation typically contributes to the performance or effectiveness of the companies that produce it. Innovation is frequently the outcome of a succession of activities and is seldom the consequence of a single individual (Janssen et al., 2004). Thus, collaboration between people or teams is critical for the efficient implementation of innovation (West, Tjosvold, \& Smith, 2003), as well as its contribution to the company's performance.

The literature states that innovation can be achieved when the processes of exploitative and exploratory knowledge creation are successfully balanced (Andriopoulos \& Lewis, 2009; Lin et al, 2013). Gurtner and Reinhardt (2016) define ambidexterity as the ability to develop incremental and radical innovations. Through their exploitation activity, a team can use their existing capabilities by integrating or enhancing their existing knowledge (March, 1991), allowing for the creation of new skills or processes associated with incremental innovation. Incremental innovations are modest adjustments that may be made to improve the quality or development of a business's goods or to complement existing technologies. While exploration activities can produce completely new knowledge, skills, and processes through research or experiments, so this activity is more related to radical innovations (March, 1991; Levinthal and March, 1993; Lin et al., 2013; Uhl- Bien \& Arena, 2018). According to the description above, this study supports that ambidexterity might help a work team generate new ideas. Additionally, prior study has demonstrated a beneficial relationship between exploration and exploitation activities, which can promote innovation (AtuaheneGima, 2005; Lin et al., 2013; Andriopoulos and Lewis, 2009).

H4. Ambidexterity has a positive effect on innovation

\section{Knowledge Sharing and Innovation}

Previous study has demonstrated that knowledge sharing among team members promotes collaborative learning, which can encourage innovation (Eisenhardt \& Tabrizi, 1995; Hu \& Randel, 2014; Lei et al., 2020). Knowledge sharing is the practice of exchanging tacit and explicit knowledge among employees in order to collaboratively develop new knowledge (Van den Hooff \& De Ridder, 2004). When exchanged between individuals, tacit knowledge sharing results in shared learning and the sharing of a varied perspective that can aid in team creativity (Eisenhardt \& Tabrizi, 1995; Leonard \& Sensiper, 1998). Individuals' diverse viewpoints can generate energy that might be harnessed into a new concept or product (Leonard \& Sensiper, 1998). While explicit knowledge sharing allows the recombination of existing ideas, which is necessary for innovation (Kogut \& Zander, 1992). Explicit knowledge sharing entails the communication of knowledge in the form of reports, processes, formal languages, manuals, or information technology systems (Coakes, 2006; Huang, Davison, \& Gu, 2010), therefore it is very important for the collaborative process involved in innovation. According to the description above, this study supports that knowledge sharing might help a work team generate innovative ideas. Additionally, previous research has also shown a positive interaction between knowledge sharing that can encourage innovation (Eisenhardt \& Tabrizi, 1995; Hu \& Randel, 2014; Lei et al., 2019).

H5. Knowledge sharing has a positive effect on innovation 


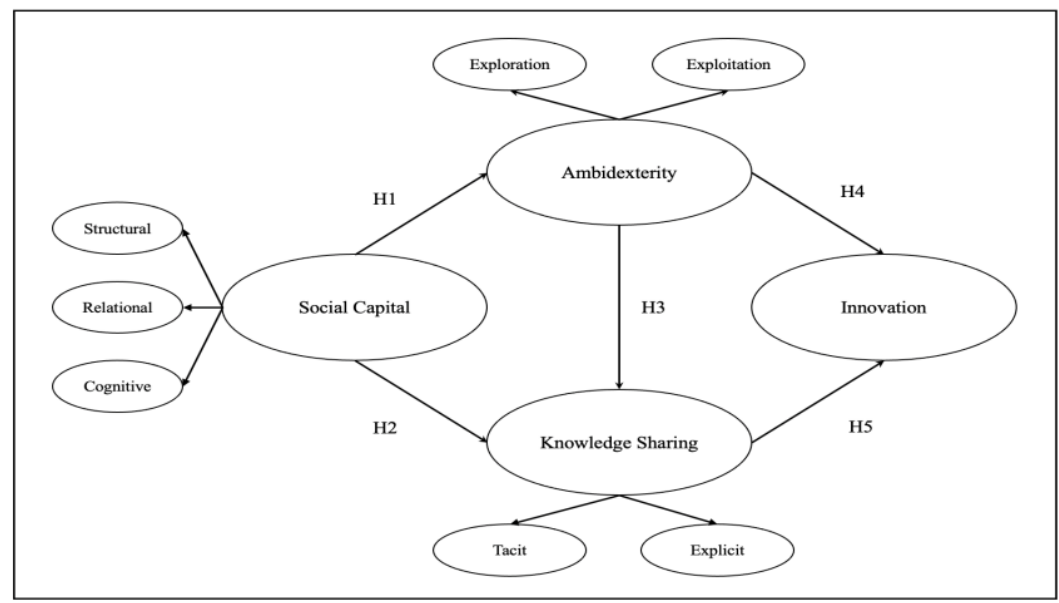

Figure 1. Research Framework

\section{Research Method}

Data Collection and Samples

This empirical research was conducted by collecting data through a survey on the work teams in PT Indocement Tunggal Prakarsa Tbk environment. The number of employees at PT Indocement is 5,684 employees. In this study the proposed sample size is 100 , and the unit analysis is the work teams at PT Indocement. In carrying out data collection, researchers made a questionnaire using Google Form. URL (link) from the Google Form containing 43 questions which were then distributed via corporate email addressed to the leaders of the work teams at PT Indocement who were at echelon level $1-4$. We also include a personal contact number if the respondent requires an explanation related to the research being conducted. Data collection was carried out during May 2021. Based on the survey that had been conducted, 69 empirical data was obtained from 150 questionnaires distributed (response rate 46\%). After an examination of answers, it was concluded that the entire incoming respondents were considered to meet the criteria as respondents.

Table 1. Profile of research samples

\begin{tabular}{lcc}
\hline \multicolumn{1}{c}{ Variable } & Total & Percentage \\
\hline Department & 22 & $31,9 \%$ \\
Plant & 47 & $68,1 \%$ \\
Division & 69 & 100 \\
Total & & \\
Position level & 1 & $1,4 \%$ \\
Echelon 1: Plant/Division & 19 & $27,5 \%$ \\
Manager & 26 & $37,7 \%$ \\
Echelon 2: Department Head & 23 & $33,3 \%$ \\
Echelon 3: Planner / Section & 69 & 100 \\
Head & & \\
Echelon 4: Supervisor & 42 & $60,9 \%$ \\
Total & 11 & $15,9 \%$ \\
Work Length & 13 & $18,8 \%$ \\
>15 Years & 3 & $4,3 \%$ \\
11 to 15 Years & 0 & $0 \%$ \\
6 to 10 Years & 69 & 100 \\
1 to 5 Years & & \\
Total & & \\
\hline
\end{tabular}


Based on table 1, if sorted from the majority, it can be seen that a number of 47 leaders of the work teams at PT Indocement who were respondents in this study were leaders in the division department (68.1\%), and 22 leaders were leader in the plant department (31.9\%). The respondent's position level if sorted from the majority can be seen that a number of 26 leaders have echelon 3 positions $(37.7 \%), 23$ leaders have echelon 4 positions (33.3\%), 19 leaders have echelon 2 positions $(27.5 \%)$, and only 1 leader has echelon 1 position $(1.4 \%)$. The majority of respondents have worked at PT Indocement for more than 15 years, with 42 leaders having worked for more than 15 years $(60.9 \%), 13$ leaders having worked for 6 to 10 years $(18.8 \%), 11$ leaders having worked for 11 to 15 years $(15.9 \%), 3$ leaders have worked for 1 to 5 years $(4.3 \%)$, and no leader has worked for less than 1 year.

\section{Measuring Instruments}

The research model includes four factors (social capital, ambidexterity, knowledge sharing, and innovation) and each factor is measured by several items. All items are adopted from existing literature to increase content validity. All items then measured using 6 likert scales starting from (1) strongly disagree, (2) disagree, (3) somewhat disagree, (4) rather agree, (5) agree and (6) strongly agree. The data obtained is then processed using Structural Equation Modeling (SEM) PLS.

The measurement of social capital is adapted from Kim et al., (2012), which is the most widely used measurement in the current literature.Each dimension is measured by five items. For ambidexterity, we measure the dimensions of exploration and exploitation using a scale adapted from the work of Kostopoulos and Bozionelos (2011) and Jansen et al. (2006). Five items are used to measure exploration and five items are used to measure exploitation. Furthermore, the measurement of knowledge sharing was adapted from Bock et al. (2005) and Wang and Wang (2012) to measure explicit and tacit knowledge sharing, each of which is measured by five items. For innovation, Burpitt and Bigoness's (1997) method of measuring innovation is adopted. Eight items are used to measure innovation.

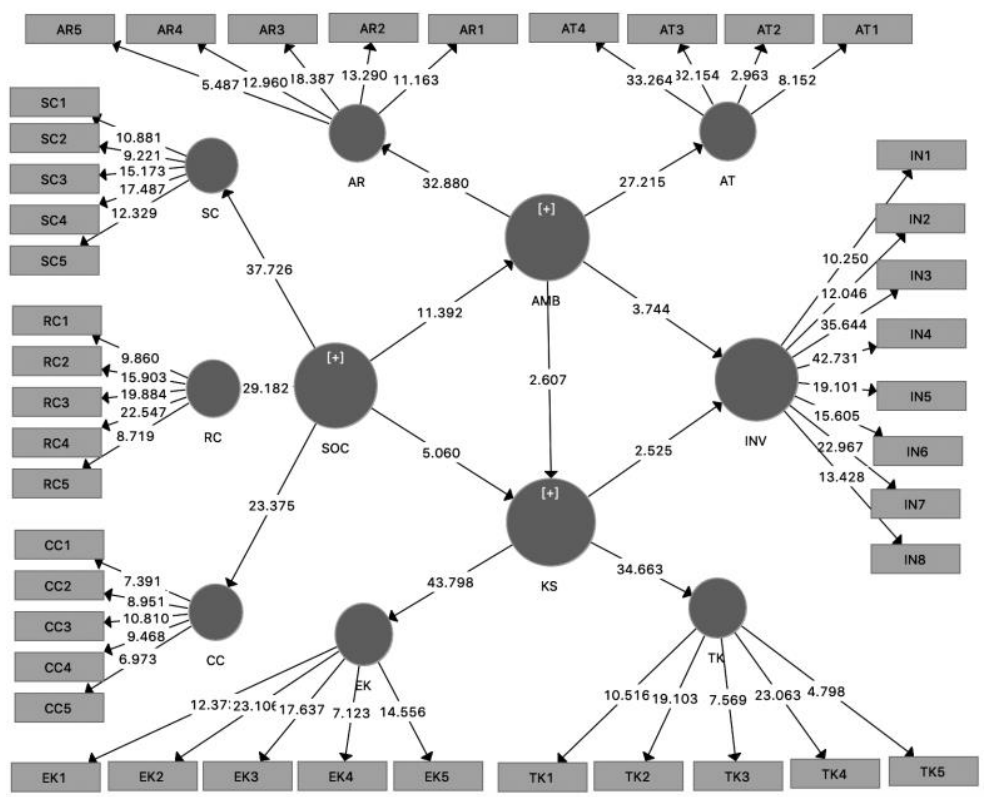

Figure 2. Hypothesis Test Results Model

\section{Results and Discussion}

From the results of the hypothesis, the t-statistical value of five hypotheses is greater than 1.96 and $\mathrm{P}$ Value is smaller than 0.05 . H1 shows that the value of t-statistic of social capital on ambidexterity is 11.392 , and the $\mathrm{P}$ value is 0,000 . This shows that there is a significant effect of social capital on ambidexterity. Therefore, H1 is declared accepted. Empirically, the finding of this study supports the research of Kostopoulos, Bozionelos, and Syrigos (2015), where social capital owned by companies can support ambidexterity. The work teams at PT Indocement acknowledged in this study that their social capital contributed significantly to the company's exploration and exploitation efforts. Social capital may both encourage and assist the interchange of views among team members, allowing each team to continuously update their expertise through increased access to diverse information and external resources. Teams that 
are capable of establishing and maintaining strong internal and external collaboration networks will be more adept at tolerating divergent viewpoints and achieving ambidextrous goals.

$\mathrm{H} 2$ shows that the value of the t-statistic of social capital on knowledge sharing is 5.060 and the value of $\mathrm{P}$ value is 0,000 . The t-statistic value is greater than 1.96 and the $P$ value is smaller than 0.05 . So it can be stated that there is a significant effect of social capital on knowledge sharing. Therefore, $\mathrm{H} 2$ is declared accepted. The finding of this study, strengthened previous studies, such as Allameh (2018) research which showed that social capital affected knowledge sharing. In this study, the work teams at PT Indocement acknowledged that social capital could improve knowledge sharing by facilitating communication between team members. High quality communication and trust among members of their team can facilitate the exchange of information and increase knowledge sharing. In other words, team members tend to share the knowledge they have with other members that they trust and have the same mindset to achieve their goals. $\mathrm{H} 3$ shows that the value of the t-statistic of ambidexterity on knowledge sharing is 2.607 and the $\mathrm{P}$ value is 0.009 . The $\mathrm{t}$-statistic value is greater than 1.96 and the $\mathrm{P}$ Value is smaller than 0.05 . So it can be stated that there is a significant effect of ambidexterity on knowledge sharing. Therefore, H2 is declared accepted. The finding of this study supports previous studies, such as Liu \& Lin et al. (2018) which proves that ambidexterity is one of the factors that facilitates knowledge sharing. In this study, the work teams at PT Indocement admitted that ambidexterity could encourage knowledge sharing in their team, where their work teams can effectively carry out collective activities and achieve many common goals without being disturbed by contradictory goals, so that these capabilities can facilitate performance and knowledge management on their team. By combining two practices that facilitate internal and external learning, the work teams are able to overcome obstacles that often appear in knowledge sharing and encourage learning. $\mathrm{H} 4$ shows that the value of the t-statistic of ambidexterity on innovation is 3.744 and the $\mathrm{P}$ value is 0,000 . The $t$-statistic value is greater than 1.96 and the $\mathrm{P}$ value is smaller than 0.05 . So it can be stated that there is a significant effect of ambidexterity on innovation. Therefore, H4 is declared accepted. The results of this study support Lin et al. (2013) research and also consistent with Batt-Rawden, Lien and Slåtten (2019) which shows that ambidexterity can encourage the creation of innovation. In this study the work teams at PT Indocement recognized that they needed to balance exploration and exploitation activities to be able to produce various types of innovation on their team. By carrying out exploitation activities they can improve their knowledge so that incremental innovation can be created. While the exploration can help them to produce completely new knowledge, skills and processes, so that radical new innovations can be created. $\mathrm{H} 5$ shows that the value of the t-statistic of knowledge sharing on innovation is 2,525 and the $\mathrm{P}$ value is 0.012 . The $t$-statistic value is greater than 1.96 and the $P$ value is smaller than 0.05 . So it can be stated that there is a significant effect of knowledge sharing on innovation. Therefore, H5 is declared accepted. The finding of this study supports previous studies, such as Lei et al research. (2019) which proves that knowledge sharing has an influence on innovation. In this study, the work teams at PT Indocement acknowledged that the knowledge sharing they had an important role in the creation of innovations needed by the company to respond to the business environmental situation that was increasingly complex and uncertain.

In this study, IN4 indicator (42,731) "My team members are willing to identify and develop skills that can support the new company business needs" have the largest loading factor on the variable innovation. This means that companies in the Indonesian cement industry can encourage innovation in their companies by providing the support their teams need to develop the skills needed to develop new companies' businesses, which are needed to survive over time from the increasing competitive pressures and unstable economic condition. The foundation of all innovations is creative ideas and individuals or groups that can produce, promote, discuss, modify, and ultimately realize these ideas (Scott \& Bruce, 1994; Van de Ven, 1986).

\section{Conclusion and Implications}

This study aims to empirically examine the effect of social capital on innovation in the context of the Indonesian cement industry. Based on the findings of this study, it can be stated that social capital can influence innovation via the mediating effects of ambidexterity and knowledge sharing. If supported by ambidexterity and knowledge sharing on each work team inside the organization, social capital held by the work team can encourage innovation. Social capital was also proven to be able to support the pursuit of ambidexterity and knowledge sharing to encourage the creation of innovation. Innovation can be achieved when the process of exploitative and exploratory knowledge creation is successfully balanced. Meanwhile, the act of tacit and explicit knowledge sharing can result in the creation of new knowledge among employees, who are critical to the team's ability to innovate. 


\section{Implications for Practitioners and Researchers}

The findings in this study have significant implications for practitioners and academics seeking to foster innovation inside their organizations, particularly in the Indonesian cement industry. Given the critical role of social capital in the development of innovation within work teams in the Indonesian cement industry, it is recommended that each team leader educates his or her members about the value of communication networks. Consideration should be given to factors such as communication, motivation, program opportunities, and promotions to encourage workers to acquire the capacity of ambidexterity and knowledge sharing required to encourage the creation of innovation in the work team.

As demonstrated by the study's findings, ambidexterity can act as a mediator between social capital and innovation. Team leaders must continue to leverage the resources of their members by motivating multitasking behavior and cultivating a culture in which members feel safe to express differing and often paradoxical views. This can be accomplished by assigning different roles and responsibilities to team members or by facilitating discussions in which employees can express diverse ideas, admit mistakes, and reflect on ways to improve.

In relation to the impact of knowledge sharing on innovation. The primary objective of knowledge sharing is to transform employees' experience, knowledge, skills, information, and expertise into company assets. To do this, it is very important to select team members who have a tendency to be able to receive and share knowledge. Creating a reward system for team members can also increase effectiveness in order to increase the active participation of team members in knowledge sharing as an effort to encourage innovation.

\section{Limitations and Future Research}

As with many other studies, this one contains limitations that may pave the way for future research. The research has limitations that focus on the context of the Indonesian cement industry and was only tested on work teams at PT Indocement. Additionally, this research is a cross-sectional study that spans only one time period, specifically during the Covid-19 pandemic. Future studies can investigate the long-term effects of the relationship assumed in this study. Furthermore, this research only focuses on ambidexterity and knowledge sharing as an intermediary between social capital and innovation. Future study can be conducted to incorporate additional components and to verify antecedents and other possible outcomes. Additionally, characteristics such as team learning capabilities might be investigated.

\section{References}

Abili, K. (2011). Social capital management in Iranian knowledge-based organizations' the electronic. Journal of Knowledge Management, Vol.9 (3), 203-210.

Adler, P., Goldoftas, B., \& Levine, D. (1999). Flexibility versus efficiency? A case study of model changeovers in the Toyota production system. Organization Science, Vol.10, 43-68.

Akhavan, P., \& Hosseini, M. (2015). Social capital, knowledge sharing, and innovation capability: an empirical study of R\&D teams in Iran. Technology Analysis \& Strategic Management, Vol.28 (1), $1-18$.

Allameh, S.M. (2018). Antecedents and consequences of intellectual capital: The role of social capital, knowledge sharing and innovation. Journal of Intellectual Capital, Vol.19 (5), 858-874.

Amabile, T. M. (1988). A model of creativity and innovation in organizations. In B. M. Staw, \& L. L. Cummings (Eds.), Research in organizational behavior, Vol.10, 187-209. Greenwich, CT: JAI Press.

Amarakoon, U., Weerawardena, J., \& Verreynne, M. L. (2018). Learning capabilities, human resource management innovation and competitive advantage. The International Journal of Human Resource Management, Vol.29, 1736-1766.

Ancona, D., \& Caldwell, D. (1987). Management issues facing new product teams in high technology companies. In D. Lewin, D. Lipsky, \& D. Sokel (Eds.), Advances in industrial and labor relations, Vol.4, 191-221). Greenwich, CT: JAI Press. 
Andriopoulos, C., \& Lewis, M.W. (2009). Exploitation-Exploration Tensions and Organizational Ambidexterity: Managing Paradoxes of Innovation. Organization Science, Vol.20 (4), 696-717.

Atuahene-Gima, K. (2005). Resolving the Capability-Rigidity Paradox in New Product Innovation. Journal of Marketing, Vol.69 (4), 61-83.

Batt-Rawden, V.H., Lien, G., \& Slåtten, T. (2019). Team learning capability-an instrument for innovation ambidexterity? International Journal of Quality and Service Sciences, Vol.11 (4), 473-486.

Bock, G.W., Zmud, R.W., Kim, Y.G., \& Lee, J.N. (2005). Behavioral Intention Formation in Knowledge Sharing: Examining the Roles of Extrinsic Motivators, Social-Psychological Forces, and Organizational Climate. MIS Quarterly, Vol.29, 87-111.

Bolino, M.C., Turnley, W.H., \& Bloodgood, J.M. (2002). Citizenship behavior and creation of social capital in organizations. Academy of Management Review, Vol.27 (4), 505-522.

Burpitt, W. J., \& Bigoness, W. J. (1997). Leadership and innovation among teams: The impact of empowerment. Small Group Research, Vol.28 (3), 414-423.

Buyl, T., Boone, C., \& Matthyssens, P. (2012). The impact of the top management team's knowledge diversity on organizational ambidexterity: a conceptual framework. International Studies of Management \& Organization, Vol.42 (4), 8-26.

Cao, Q.; Gedajlovic, E.; Zhang, H. (2009). Unpacking Organizational Ambidexterity: Dimensions, Contingencies, and Synergistic Effects. Organization Science, Vol.20 (4), 781-796.

Carlsson, B. (1989). Flexibility and the theory of the firm. International Journal of Industrial Organization, Vol.7, 179-203.

Chow, W.S., \& Chan, L.S. (2008). Social network, social trust and shared goals in organizational knowledge sharing. Information \& Management, Vol.45 (7), 458-465.

Coakes, E. (2006). Storing and sharing knowledge: Supporting the management of knowledge made explicit in transnational organizations. The Learning Organization, Vol.13 (6), 579-593.

Cohen, D., \& Prusak, L. (2001). In Good Company: How Social Capital Makes Organizations Work. Harvard Business Press, Boston, MA.

Damanpour, F. (1991). Organizational innovation: A meta-analysis of effects of determinants and moderators. Academy of Management Journal, Vol.34 (3), 555-590.

Danneels, E. (2002). The dynamics of product innovation and firm competences. Strategic Management Journal, Vol.23 (12), 1095-1121.

Darroch, J. and McNaughton, R. (2002). Examining the Link between Knowledge Management Practices and Types of Innovation. Journal of Intellectual Capital, Vol.3, 210-222.

Eisenhardt, K.M., \& Tabrizi, B.N. (1995) Accelerating Adaptive Processes: Product Innovation in the Global Computer Industry. Administrative Science Quarterly, Vol.40, 84-110.

Enkel, E., Heil S., Hengstler, M., Wirth, H. (2017). Exploratory and exploitative innovation: to what extent do the dimensions of individual level absorptive capacity contribute? Technovation, Elsevier, Vol.60, 29-38.

Gibson, C.B., \& Birkinshaw, J. (2004). The Antecedents, Consequences, and Mediating Role of Organizational Ambidexterity. The Academy of Management Journal, Vol.47 (2), 209-226.

Gurtner, S., \& Reinhardt, R. (2016). Ambidextrous Idea Generation-Antecedents and Outcomes*. Journal of Product Innovation Management, Vol.33 (1), 34-54.

Hill, S. A.\& Birkinshaw, J. (2012). Ambidexterity and Survival in Corporate Venture Units. Journal of Management, Vol.40 (7), 1899-1931.

He, Z.L., \& Wong, P.K. (2004). Exploration vs. exploitation: an empirical test of the ambidexterity hypothesis. Organization Science, Vol.15 (4), 481-494.

Holste, J.S.; Fields, D. (2010). Trust and tacit knowledge sharing and use. Journal of Knowledge Management, Vol.14 (1), 128-140.

Hu, L.\& Randel, A. E. (2014). Knowledge Sharing in Teams: Social Capital, Extrinsic Incentives, and Team Innovation. Group \& Organization Management, Vol.39 (2), 213-243.

Huang, Q., Davison, R.M., \& Gu, J. (2008). Impact of personal and cultural factors on knowledge sharing 106

(C) 2020. The $5^{\text {th }}$ International Conference on Family Business and Entrepreneurship. 
in China. Asia Pacific Journal of Management, Vol.25 (3), 451-471.

Huang, Q., Davison, R.M., \& Gu, J. (2011). The impact of trust, guanxi orientation and face on the intention of Chinese employees and managers to engage in peer-to-peer tacit and explicit knowledge sharing. Information Systems Journal, Vol.21 (6), 557-577.

Jansen, J.J.P., van den Bosch, F.A.J., \& Volberda, H.W. (2006). Exploratory innovation, exploitative innovation, and performance: effects of organizational antecedents and environmental moderators. Management Science, Vol. 52 (11), 1661-1674.

Janssen, O.; Van de Vliert, E.; West, M. (2004). The bright and dark sides of individual and group innovation: a Special Issue introduction. Journal of Organizational Behavior, Vol.25 (2), 129-145.

Kang, S., \& Snell, S.A. (2009). Intellectual Capital Architectures and Ambidextrous Learning: A Framework for Human Resource Management. Journal of Management Studies, Vol.46 (1), 65-92.

Kanter, R. (1988). When a thousand flowers bloom: structural, collective, and social conditions for innovation in organizations. In B. M. Staw, \& L. L. Cummings (Eds.), Research in organizational behavior, Vol.10, 169-211). Greenwich, CT: JAI Press.

Katila, R., \& Ahuja G. (2002). Something Old, Something New: A Longitudinal Study of Search Behavior and New Product Introduction. The Academy of Management Journal, Vol.45 (6), 1183-1194.

Kauppila, O.P. (2010). Creating ambidexterity by integrating and balancing structurally separate interorganizational partnerships. Strategic Organization, Vol.8 (4), 283-312.

Kim, T., \& Lee, G. (2010). Examining social capital and knowledge sharing as antecedents of service innovativeness and business performance in the hotel industry: an application of the resource-based view (RBV) theory. Journal of Tourism Sciences, Vol.34 (7), 13-36.

Kim, T., Lee, G., Paek, S., \& Lee, S. (2012). Social capital, knowledge sharing and organizational performance: what structural relationship do they have in hotels? International Journal of Contemporary Hospitality Management, Vol.25 (5), 683-704.

Kogut, B., \& Zander, U. (1992). Knowledge of the firm, combinative capabilities, and the replication of technology. Organization Science, Vol.3 (3), 383-397.

Kostopoulos, K.C., \& Bozionelos, N. (2011). Team Exploratory and Exploitative Learning: Psychological Safety, Task Conflict, and Team Performance. Group \& Organization Management, Vol.36 (3), 385-415.

Kostopoulos, K.C., Bozionelos, N., \& Syrigos, E. (2015). Ambidexterity and unit performance: Intellectual capital antecedents and cross- level moderating effects of human resource practices. Human Resource Management, Vol.54(1), 111-132.

Leana, C.R., \& Van Buren, H.J. (1999). Organizational social capital and employment practices. Academy of Management Review, Vol.24 (3), 538-555.

Lee Endres, M.; Endres, S.P.; Chowdhury, S.K.; Alam, I. (2007). Tacit knowledge sharing, self-efficacy theory, and application to the Open Source community. Journal of Knowledge Management, Vol.11 (3), 92-103.

Lei, H., Ha, A.T.L., \& Le, P.B. (2019). How ethical leadership cultivates radical and incremental innovation: the mediating role of tacit and explicit knowledge sharing. Journal of Business \& Industrial Marketing, Vol.35 (5), 849-862.

Leonard, D., \& Sensiper, S. (1998). The role of tacit knowledge in group innovation. California Management Review, Vol.40, 112-132.

Levinthal, D., \& March, J. (1993). The myopia of learning. Strategic Management Journal, Vol.12, 95112.

Lin, C. (2007). To Share or Not to Share: Modeling Tacit Knowledge Sharing, Its Mediators and Antecedents. Journal of Business Ethics, Vol.70 (4), 411-428.

Lin, H. (2007). Knowledge sharing and firm innovation capability: an empirical study. International Journal of Manpower, Vol.28 (3/4), 315-332.

Lin, H.; McDonough, E.F.; Lin, S.; Lin, C.Y. (2013). Managing the Exploitation/Exploration Paradox: The Role of a Learning Capability and Innovation Ambidexterity. Journal of Product Innovation 
Management, Vol.30 (2), 262-278.

Liu, M.; Lin, C.; Joe, S.; Chen, K. (2018). Modeling knowledge sharing and team performance. Management Decision, Vol.57 (1), 0025-1747.

Lu, L., Leung, K. \& Koch, P.T. (2006). Managerial knowledge sharing: the role of individual, interpersonal, and organizational factors. Management and Organization Review, Vol.2, 15-41.

Malhotra, N.K. (2009). Review of Marketing Research. Review of Marketing Research, Vol.5, 9-16.

March, J.G. (1991). Exploration and exploitation in organizational learning. Organization Science, Vol.2, 71-86.

Mom, T.J.M.; van den Bosch, F.A.J.; Volberda, H.W. (2009). Understanding Variation in Managers' Ambidexterity: Investigating Direct and Interaction Effects of Formal Structural and Personal Coordination Mechanisms. Organization Science, Vol.20 (4), 812-828.

Mumford, M. D. (2000). Managing creative people: strategies and tactics for innovation. Human Resource Management Review, Vol.10, 313-351.

Nahapiet, J., \& Ghoshal, S. (1998). Social capital, intellectual capital and organizational advantage. Academy of Management Review, Vol.23 (2), 242-266.

Nonaka, I., \& Takeuchi, K. (1995). The Knowledge Creating Company. New York, NY: Oxford University Press.

Polanyi, M. (1966). The Logic of Tacit Inference. Philosophy, Vol.41 (155), 1.

PT Indocement Tunggal Prakarsa. (2018). Annual Report: Turnaround Unlocking The Future.

PT Indocement Tunggal Prakarsa. (2020). Annual Report: Smarter Faster Better.

Raisch, S., \& Birkinshaw, J. (2008). Organizational ambidexterity: antecedents, outcomes, and moderators. Journal of Management, Vol. 34 No. 3, pp. 375-409.

Reagans, R., \& McEvily, B. (2003). Network Structure and Knowledge Transfer: The Effects of Cohesion and Range. Administrative Science Quarterly, Vol.48 (2), 240-267.

Scott, S. G., \& Bruce, R. A. (1994). Determinants of innovative behavior: a path model of individual innovation in the workplace. Academy of Management Journal, Vol.37, 580-607.

Simsek, Z., Veiga, J.F., Lubatkin, M.H., \& Dino, R.N. (2005). Modeling the multilevel determinants of top management team behavioral integration. Academy of Management Journal, Vol.48 (1), 69-84.

Suarez, L.M.N. (2001). Effects of handedness on completion time during performance of multiple tasks using 'proper' and 'improper' tools. Paper 192, Theses, Daytona Beach, FL.

Tiwana, A. (2008). Do bridging ties complement strong ties? An empirical examination of alliance ambidexterity. Strategic Management Journal, Vol.29 (3), 251-272.

Uhl-Bien, M., \& Arena, M. (2018). Leadership for organizational adaptability: A theoretical synthesis and integrative framework. The Leadership Quarterly, Vol.29 (1), 89-104.

Van den Hooff, B., \& Huysman, M. (2009). Managing knowledge sharing: Emergent and engineering approaches. Information \& Management, Vol.46 (1), 1-8.

Van de Ven, A. (1986). Central problems in the management of innovation. Management Science, Vol.32, 590-607

Wang, M., Chen, S., \& Chiang, J. (2017). Rationality of the personal loan interest-ratemarkups of banks. Corporate Management Review, Vol.37 (1), 115-163.

Wang, S., \& Noe, R.A. (2010). Knowledge sharing: A review and directions for future research. Human Resource Management Review, Vol.20 (2), 115-131.

Wang, Z., \& Wang, N. (2012). Knowledge sharing, innovation and firm performance. Expert Systems with Applications, Vol.39 (10), 8899-8908.

Wasko, M.M., \& Faraj, S. (2005). Why should I share? Examining social capital and knowledge contribution in electronic networks of practices. MIS Quarterly, Vol.29 (1), 35-57.

West, M.; Tjosvold, D.; Smith, K.G. (2003). International handbook of organizational teamwork and cooperative working. John Wiley and Sons, Chichester.

West, M.A., \& Farr, J.L. (1989). Innovation at Work: Psychological Perspectives. Social Behavior,

Vol.4, 15-30. 
Woodman, R. W., Sawyer, J. E., \& Griffin, R. W. (1993). Toward a theory of organizational creativity. Academy of Management Review, Vol.18, 293-321. 